\title{
Crude extract and solvent fractions of Calystegia soldanella induce $G 1$ and $S$ phase arrest of the cell cycle in HepG2 cells
}

\author{
JUNG IM LEE ${ }^{1 *}$, IN-HYE KIM $^{1 *}$ and TAEK-JEONG NAM ${ }^{1,2}$ \\ ${ }^{1}$ Institute of Fisheries Science, Pukyong National University, Ilgwang-myeon, Gijang-gun, Busan 619-911; \\ ${ }^{2}$ Department of Food Science and Nutrition, Pukyong National University, Nam-gu, Busan 48513, Republic of Korea
}

Received October 30, 2016; Accepted December 23, 2016

DOI: 10.3892/ijo.2017.3836

\begin{abstract}
The representative halophyte Calystegia soldanella (L) Roem. et Schult is a perennial vine herb that grows in coastal dunes throughout South Korea as well as in other regions around the world. This plant has long been used as an edible and medicinal herb to cure rheumatic arthritis, sore throat, dropsy, and scurvy. Some studies have also shown that this plant species exhibits various biological activities. However, there are few studies on cytotoxicity induced by C. soldanella treatment in HepG2 human hepatocellular carcinoma cells. In this study, we investigated the viability of HepG2 cells following treatment with crude extracts and four solvent-partitioned fractions of $C$. soldanella. Of the crude extract and four solvent fractions tested, treatment with the $85 \%$ aqueous methanol (aq. $\mathrm{MeOH}$ ) fraction resulted in the greatest inhibition of HepG2 cell proliferation. Flow cytometry showed that the $85 \%$ aq. $\mathrm{MeOH}$ fraction induced a G0/G1 and $\mathrm{S}$ phase arrest of the cell cycle progression. The $85 \%$ aq. $\mathrm{MeOH}$ fraction arrested HepG2 cells at the G0/G1 phase in a concentration-dependent manner, and resulted in decreased expression of cyclin D1, cyclin E, cyclin-dependent kinase (CDK)2, CDK4, CDK6, p21, and p27. Additionally, the $85 \%$ aq. $\mathrm{MeOH}$ fraction treatment also arrested HepG2 cells in the $\mathrm{S}$ phase, with decreased expression of cyclin $\mathrm{A}$, CDK2, and CDC25A. Also, treatment with this fraction reduced the expression of retinoblastoma $(\mathrm{RB})$ protein and the transcription factor E2F. These results suggest that the $85 \%$ aq. $\mathrm{MeOH}$ fraction exhibits potential anticancer activity in HepG2 cells by inducing G0/G1 and S phase arrest of the cell cycle.
\end{abstract}

Correspondence to: Professor Taek-Jeong Nam, Department of Food Science and Nutrition, Pukyong National University, 45 Yongso-ro, Nam-gu, Busan 48513, Republic of Korea

E-mail:namtj@pknu.ac.kr

${ }^{*}$ Contributed equally

Key words: Calystegia soldanella, methanol fraction, HepG2 cells, cell cycle arrest, cell cycle checkpoint protein

\section{Introduction}

Cancer is an obstinate disease with high morbidity and mortality, and the incidence rate is predicted to increase over the coming years (1). Although various therapies have been developed for the treatment of cancer, the mortality rate remains high $(2,3)$. Hepatocellular carcinoma is one of the most common gastrointestinal malignancies. It is the sixthleading cause of cancer-related death in the United States (4). The prognosis of hepatocellular carcinoma is poor due to high malignancy. Although biochemical and clinical studies have led to significant advances, the 7-year (2004-2010) survival rate remains $<18 \%$ (4). Most of the poor prognoses were associated with recurrence and metastasis following treatment, including curative resection (5). Common treatments including surgery, chemotherapy, radiotherapy, interventional treatment and liver transplantation could only provide limited clinical results (6). Traditional chemotherapy and radiotherapy cause intrinsic and potential cytotoxicity in normal cells, and extended use of these therapies can lead to drug resistance and side effects, such as hair loss, vomiting, nausea, and the occurrence of secondary cancers (1). Due to the limitations of conventional therapies, it is important to find safer, more targeted anticancer agents. New outstanding strategy for cancer chemoprevention and chemotherapeutic are also required to including the cell cycle arrest and apoptosis of cancer cells that grow abnormally by deregulating the cell cycle control. Recently, there has been growing interest in searching for novel and effective anticancer agents from natural sources, especially from marine organisms (7-19).

Halophytes are plants that tolerate high salt concentrations, and can grow in salt marshes, mangrove swamps, seashores, coastal sand dune regions, and estuarine environments (20). Environmental stress and ecological factors, such as drought, salt spray, floods, high temperature, low capillary water holding activity of sandy soil, low nutrients, and water availability affect the plant's metabolism and survival (21-23). In these environments, halophytes need to conform to develop stress adaptation responses for survival. As a result, these salt marsh plants are predicted to be an important source in the search for novel and unique bioactive secondary metabolites (24-30).

Calystegia soldanella(L) Roem. et Schult(Convolvulaceae), a representative halophyte and endemic plant, is found on 
coastal sand dunes and foredunes where the environmental stresses are significant. These plants are perennial vine herbs with ubiquitous distribution in the coastal dune areas of South Korea, East Asia, Europe, and the Pacific (31). This plant has long been used as an edible and medicinal herb to cure rheumatic arthritis, sore throat, dropsy, and scurvy (32). Some studies have shown that this plant species exhibits various biological activities. Another species, $C$. japonica, which has been used as a traditional medicine to treat urination problems, fever, or diarrhea in Chinese and oriental herb medicine $(33,34)$. Moreover, $C$. soldanella has been shown to exhibit a number of biological activities, including anti-inflammatory, antiviral, antifungal, anticancer, and analgesic properties, and more specifically, inhibition of protein tyrosine phosphate 1B (PTP1B) (35-42). Methanol extracts of $C$. soldanella decreased NO production, iNOS protein, and mRNA expression in LPS-activated Raw 264.7 cells (35). Water extracts of $C$. soldanella induced anti-inflammatory and analgesic effects in mice (36). Alkyl $p$-coumarates of an $n$-hexane fraction from a $C$. soldanella extract inhibited PTP1B activity in vitro (37). Resin glycosides from $C$. soldanella, calysolins V-IX, X-XIII, and XIV-XVII, induced antiviral activity against the herpes simplex virus type 1 (HSV-1) (39-41,43-46). An active fraction of Ipomoea carnea subsp. fistulosa (Convulvulaceae) induced antifungal activity in Colletotrichum gloeosporioides and Cladosporium cucumerinum (42).

Active components from $C$. soldanella are nortropane alkaloids, anthocyanin, coumaric acids, and flavonoids (47-50). Moreover, chloroform extracts showed both cytotoxic activities $\left[\mathrm{ED}_{50} 2 \mu \mathrm{g} / \mathrm{ml}\right.$ in UISO (squamous cell cervix carcinoma); $\mathrm{ED}_{50} 7 \mu \mathrm{g} / \mathrm{ml}$ in $\mathrm{KB}$ (nasopharyngeal carcinoma)] and antibacterial (MIC $14.7 \mu \mathrm{g} / \mathrm{ml}$ in Bacillus subtilis) $(43,44)$. Methanol extract also exhibited potential cytotoxicity against A549 lung $\left(\mathrm{IC}_{50} 8.0 \mu \mathrm{g} / \mathrm{ml}\right)$ and $\mathrm{Col} 2$ colon $\left(\mathrm{IC}_{50} 27.4 \mu \mathrm{g} / \mathrm{ml}\right)$ cancer cells (38). However, studies of the anticancer effect of $C$. soldanella have not been extensive focused on cytotoxicity. To find active components with anticancer activity, this study investigated the cytotoxic activity of crude extract and four solvent-partitioned fractions of $C$. soldanella in HepG2 human hepatocellular carcinoma cells. Furthermore, the $85 \%$ aqueous methanol (aq. $\mathrm{MeOH}$ ) fraction, which exhibited the greatest cytotoxic effect, was evaluated for cell cycle distribution and the expression of several cell cycle checkpoint proteins.

\section{Materials and methods}

Plant material. The C. soldanella whole plant was collected from Gijang, Busan, Korea in July, 2013 by Professor Y. Seo. A voucher specimen was deposited at the Herbarium of the Division of Marine Environment and Bioscience, Korea Maritime and Ocean University, Korea. The collected sample was briefly air-dried under shade, chopped into small pieces, ground into a powder, and stored at $-25^{\circ} \mathrm{C}$.

Extraction and fractions. Samples (800 g) were extracted for 2 days with methylene chloride $\left(\mathrm{CH}_{2} \mathrm{Cl}_{2} ; 10 \mathrm{~L} \mathrm{x} \mathrm{2}\right)$ and methanol (MeOH; $10 \mathrm{~L}$ x 2). The combined crude extracts $(106.51 \mathrm{~g})$ were evaporated under reduced pressure and partitioned between $\mathrm{CH}_{2} \mathrm{Cl}_{2}$ and water. The organic layer was further partitioned into $n$-hexane $(19.19 \mathrm{~g})$ and $85 \%$ aq.
$\mathrm{MeOH}(22.47 \mathrm{~g})$. The aqueous layer was also fractionated with n-butanol (BuOH; $10.48 \mathrm{~g}$ ) and water (57.66 g), successively.

Cell culture. The HepG2 human hepatocellular carcinoma cells (ATCC HB-8065) were obtained from the American Type Culture Collection (ATCC; MD, USA). Cells were cultured in modified essential medium (MEM) supplemented with $10 \%$ fetal bovine serum containing $50 \mu \mathrm{g} / \mathrm{ml}$ penicillin, $25 \mu \mathrm{g} / \mathrm{ml}$ amphotericin B, and $50 \mu \mathrm{g} / \mathrm{ml}$ streptomycin in a humidified atmosphere with $5 \% \mathrm{CO}_{2}$ at $37^{\circ} \mathrm{C}$. The medium was changed 2 or 3 times every week.

Cell viability assay. Cell viability was evaluated using the CytoX cell viability assay kit (LPS solution, Daejeon, Korea). The cells were seeded at a density of $1 \times 10^{5}$ cells/ well in a 96-well plate. After $24 \mathrm{~h}$, the cells were washed with serum-free medium (SFM) for $4 \mathrm{~h}$ and the media were replaced with fresh SFM containing different concentrations of samples. After $24 \mathrm{~h}$ of incubation, $20 \mu \mathrm{l}$ of CytoX solution was added to each well and incubated for $4 \mathrm{~h}$. The amount of formazan crystals was determined by measuring the absorbance at $450 \mathrm{~nm}$ using a FilterMax F5 microplate reader (Molecular Devices LLC, CA, USA). Cell viability was estimated by comparison with the relative absorbance value of the untreated sample.

Cell cycle analysis. Cells were seeded at a density of $1 \times 10^{4}$ cells/well and treated with different concentrations of sample for $24 \mathrm{~h}$. Control and treated cells were harvested, washed in cold phosphate-buffered saline (PBS), fixed in $70 \%$ ethanol, and stored at $4^{\circ} \mathrm{C}$. The resulting cells were stained with $200 \mu \mathrm{l}$ of Muse cell cycle reagent at room temperature for $30 \mathrm{~min}$ in the dark prior to analysis. DNA content was assessed with the Muse cell analyzer (EMD Millipore Co., CA, USA).

Western blot analysis. Following treatment with different concentrations of samples, cells were washed twice with PBS and lysed in RIPA buffer [1\% Nonidet ${ }^{\mathrm{TM}}$ P-40, 1 mM EDTA, $50 \mathrm{mM}$ Tris ( $\mathrm{pH} 7.4$ ), $0.25 \%$ Na-deoxycholate, $150 \mathrm{mM} \mathrm{NaCl}$, $1 \mathrm{mM} \mathrm{NaF}, 1 \mathrm{mM}$ sodium orthovanadate, $1 \mathrm{mM}$ PMSF]. The cell lysates were centrifuged at $12,000 \mathrm{rpm}$ for $15 \mathrm{~min}$ at $4^{\circ} \mathrm{C}$ and the supernatants were collected. The protein concentrations were determined using a BCA protein assay kit (Pierce Biotechnology, Inc., IL, USA). The proteins were treated with SDS sample buffer and heated at $95^{\circ} \mathrm{C}$ for $10 \mathrm{~min}$. The protein samples were separated by $12 \%$ SDS-PAGE, and transferred to a polyvinylidene difluoride membrane (Millipore Corp., MA, USA). The membranes were blocked by incubation with $1 \%$ bovine serum albumin (BSA) in Tris-buffered salineTween-20 [TBS-T; $10 \mathrm{mM}$ Tris- $\mathrm{HCl}, 150 \mathrm{mM} \mathrm{NaCl}$ (pH 7.5) containing $0.1 \%$ Tween-20] at room temperature for $1 \mathrm{~h}$ and incubated for $3 \mathrm{~h}$ with primary antibodies against GAPDH, cyclin D, cyclin E, cyclin A, cyclin-dependent kinase (CDK)2, CDK4, CDK6, CDC25A, p21, p27, retinoblastoma (RB), and E2F (Santa Cruz Biotechnology, Inc., TX, USA). The membranes were washed three times with TBS-T and incubated for $2 \mathrm{~h}$ with the appropriate HRP-conjugated goat anti-rabbit, goat anti-mouse, or rabbit anti-goat secondary antibodies (Santa Cruz Biotechnology, Inc.) diluted to 1:10,000 in 


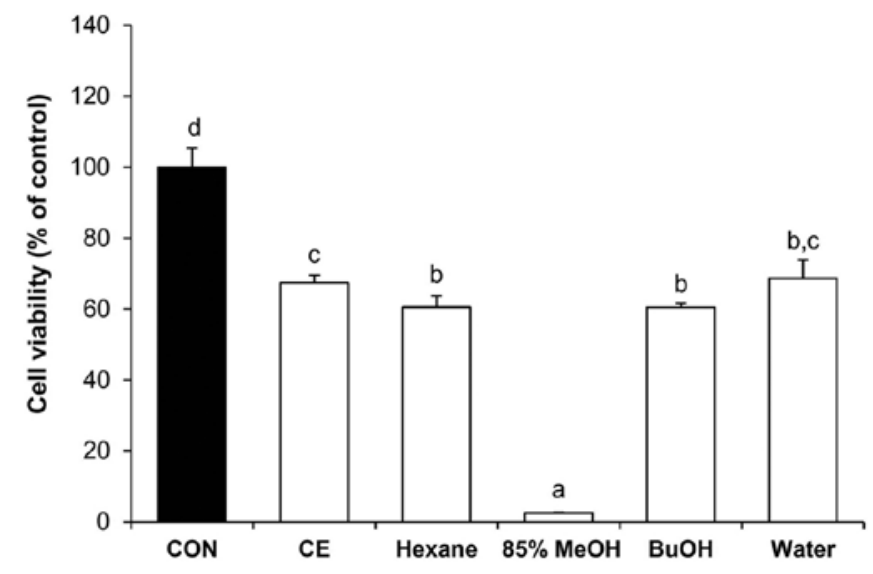

Figure 1. Cell viability of HepG2 cells following treatment with $50 \mu \mathrm{g} / \mathrm{ml}$ crude extract or solvent fractions of Calystegia soldanella. The effect of treatment of crude extract and solvent fractions of $C$. soldanella on cell viability was measured in HepG2 cells by CytoX assay. Cells were treated with a concentration of $50 \mu \mathrm{g} / \mathrm{ml}$ crude extract or solvent fractions of $C$. soldanella. Data are presented as the mean \pm standard deviation (SD) from three independent experiments. The different letters represent significant differences $(\mathrm{p}<0.05)$ as determined by Duncan's multiple range test.

TBS-T with $1 \%$ BSA. The respective proteins were detected using a chemiluminescent substrate (Advansta, CA, USA) and visualized on a GeneSys imaging system (SynGene Synoptics, Ltd., London, UK).

Statistical analysis. The data are presented as mean \pm standard deviation (SD). Differences between the means of the individual groups were analyzed using an analysis of variance (ANOVA) with Duncan's multiple range tests performed in SPSS software (SPSS Inc., IL, USA). A p-value $<0.05$ was considered to indicate statistical significance.

\section{Results}

Crude extracts and solvent fractions of $C$. soldanella decrease the viability of HepG2 cells. Effects of the crude extract and the four solvent fractions of C. soldanella on the proliferation of HepG 2 cells were examined using the CytoX cell viability assay kit. As shown in Fig. 1, the growth of HepG2 cells was inhibited at a concentration of $50 \mu \mathrm{g} / \mathrm{ml}$. The crude extract inhibited cell proliferation by $37 \%$. The crude extract was fractioned into $n$-hexane, $85 \%$ aq. $\mathrm{MeOH}, n$ - $\mathrm{BuOH}$, and water soluble fractions, treatment which inhibited proliferation by 39, 97, 40 and 31\%, respectively. Of the four solvent fractions tested, the $85 \%$ aq. $\mathrm{MeOH}$ fraction caused the greatest inhibition of HepG2 cell proliferation.

The $85 \%$ aq. $\mathrm{MeOH}$ fraction from $\mathrm{C}$. soldanella decreases the viability of HepG2 cells. To determine the effect of the $85 \%$ aq. $\mathrm{MeOH}$ fraction from $C$. soldanella on the viability of HepG2 cells, the cells were treated with $3,6,12,25$, or $50 \mu \mathrm{g} / \mathrm{ml}$ of the $85 \%$ aq. $\mathrm{MeOH}$ fraction for $24 \mathrm{~h}$. As shown in Fig. 2, treatment with $85 \%$ aq. $\mathrm{MeOH}$ reduced the viability of HepG2 cells in a concentration-dependent manner compared with the control group $(3 \mu \mathrm{g} / \mathrm{ml}, 95.9 \% ; 6 \mu \mathrm{g} / \mathrm{ml}, 90.6 \% ; 12 \mu \mathrm{g} / \mathrm{ml}$, $71.1 \% ; 25 \mu \mathrm{g} / \mathrm{ml}, 20.8 \%$; and $50 \mu \mathrm{g} / \mathrm{ml}, 22.7 \%$ ). In subsequent

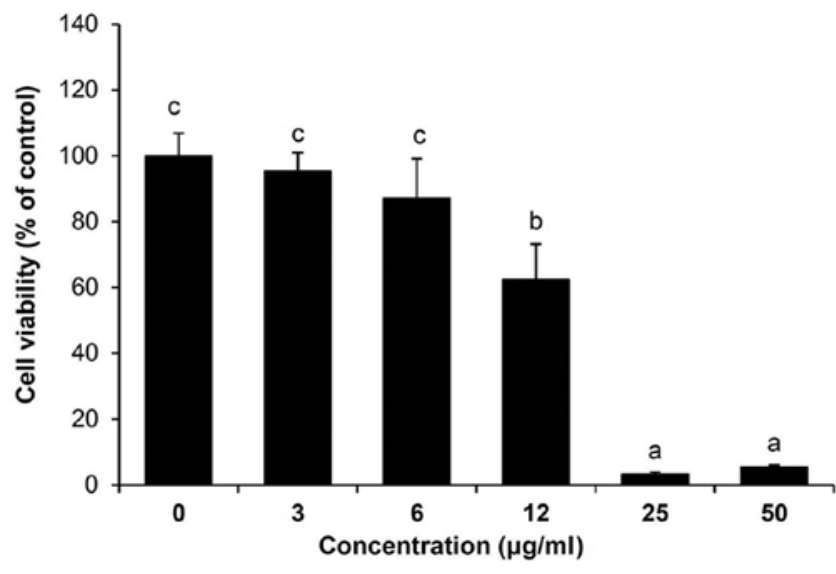

Figure 2. Cell viability of HepG2 cells following treatment with the $C$. soldanella $85 \%$ aqueous methanol (aq. $\mathrm{MeOH}$ ) fraction. The effects of treatment with the $85 \%$ aq. $\mathrm{MeOH}$ fraction from $C$. soldanella on cell viability were determined in HepG2 cells by CytoX assay. Cells were treated with the indicated concentrations of the $85 \%$ aq. $\mathrm{MeOH}$ fraction of $C$. soldanella. Data are presented as the mean \pm SD from three independent experiments. The different letters at all concentrations represent significant differences $(\mathrm{p}<0.05)$ as determined by Duncan's multiple range test.

Table I. Induction of G0/G1 and S arrest in HepG2 cells following treatment with the $85 \%$ aq. $\mathrm{MeOH}$ fraction of C. soldanella.

\begin{tabular}{lccc}
\hline & \multicolumn{3}{c}{$\%$ of cells } \\
\cline { 2 - 4 } $\begin{array}{l}\text { Concentration } \\
(\mu \mathrm{g} / \mathrm{ml})\end{array}$ & $\mathrm{G} 0 / \mathrm{G} 1$ & $\mathrm{~S}$ & $\mathrm{G} 2 / \mathrm{M}$ \\
\hline 0 & & & \\
3 & $60.47 \pm 0.85^{\mathrm{a}}$ & $12.87 \pm 0.21^{\mathrm{a}}$ & $25.20 \pm 0.87^{\mathrm{c}}$ \\
6 & $63.80 \pm 1.42^{\mathrm{b}}$ & $14.57 \pm 0.71^{\mathrm{b}}$ & $19.60 \pm 1.37^{\mathrm{b}}$ \\
12 & $64.97 \pm 0.90^{\mathrm{b}}$ & $16.10 \pm 2.16^{\mathrm{c}}$ & $15.43 \pm 0.31^{\mathrm{a}}$ \\
& $69.60 \pm 3.44^{\mathrm{c}}$ & $16.77 \pm 1.59^{\mathrm{c}}$ & $16.40 \pm 0.70^{\mathrm{a}}$
\end{tabular}

The cells were treated with the indicated concentrations of the $85 \%$ aq. $\mathrm{MeOH}$ fraction from $C$. soldanella for $24 \mathrm{~h}$. The cells were collected, fixed, and stained with propidium iodide for flow cytometric analysis. The different letters at all concentrations represent significant differences $(p<0.05)$ as determined by Duncan's multiple range test.

experiments, cells were treated with 3,6 , or $12 \mu \mathrm{g} / \mathrm{ml}$ of the $85 \%$ aq. $\mathrm{MeOH}$ fraction from $C$. soldanella for $24 \mathrm{~h}$.

The $85 \%$ aq. MeOH fraction from C. soldanella induces a G0/ $G 1$ and $S$ arrest in HepG2 cells. Flow cytometric analysis of the cell cycle of HepG2 cells showed that the number of cells in $\mathrm{G} 0 / \mathrm{G} 1$ phase significantly increased from $60.47 \pm 0.85 \%$ in the control group to $63.80 \pm 1.42,64.97 \pm 0.90$ and $69.60 \pm 3.44 \%$ in the groups treated with the various concentrations of the C. soldanella $85 \%$ aq. $\mathrm{MeOH}$ fraction (Table I). In addition, the number of cells in $\mathrm{S}$ phase significantly increased from $12.87 \pm 0.21 \%$ in the control group to $14.57 \pm 0.70,16.10 \pm 2.16$ and $16.77 \pm 1.59 \%$ in the groups treated with the $C$. soldanella $85 \%$ aq. $\mathrm{MeOH}$ fraction. The population of HepG2 cells in $\mathrm{G} 2 / \mathrm{M}$ was significantly reduced following treatment with the 
A

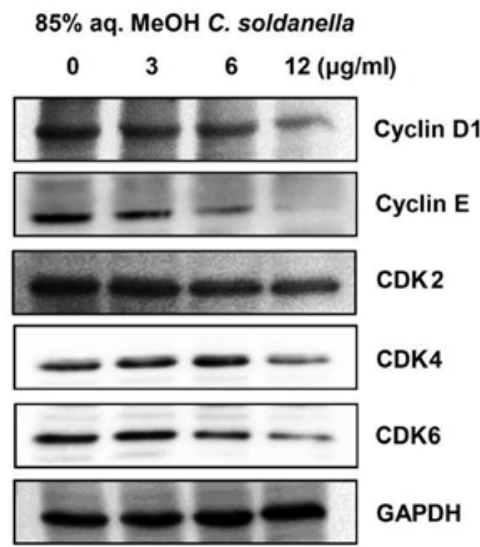

B

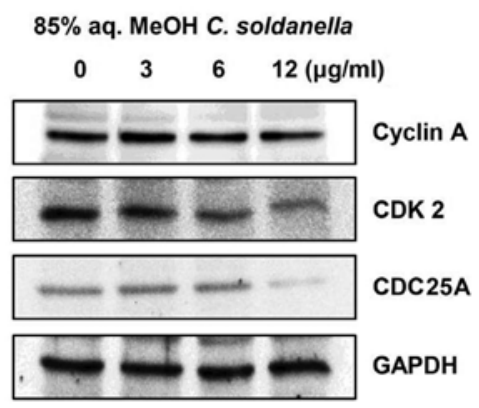

Figure 3. Downregulation of G0/G1 and S phase-associated cyclins and CDKs in HepG2 cells following treatment with the 85\% aq. MeOH fraction of C. soldanella. (A) HepG2 cells were treated with the indicated concentrations of the $85 \%$ aq. MeOH fraction from $C$. soldanella for $24 \mathrm{~h}$. The cell lysates were separated, and equal amounts of total cell lysate were subjected to SDS-PAGE analysis. G0/G1-associated protein levels of cyclin D1, cyclin E, CDK2, CDK4, and CDK6 were examined by western blotting. The bands were normalized to an internal control, GAPDH. (B) S phase-associated protein levels of cyclin A, $\mathrm{CDK} 2$, and CDC25A were examined by western blotting. Data are presented as the mean $\pm \mathrm{SD}(\mathrm{p}<0.05)$ from three independent experiments.

$85 \%$ aq. $\mathrm{MeOH}$ fraction from $C$. soldanella. These results suggest that treatment with the $C$. soldanella $85 \%$ aq. $\mathrm{MeOH}$ fraction arrests HepG2 cells in the G0/G1 and $\mathrm{S}$ phases of the cell cycle, and that the reduced viability of HepG2 cells following treatment with the $85 \%$ aq. $\mathrm{MeOH}$ fraction is likely the result of these cell cycle blocks.

The $85 \%$ aq. $\mathrm{MeOH}$ fraction from $C$. soldanella regulates cell cycle checkpoint proteins in HepG2 cells. To investigate the cell cycle arrest induced by the $85 \%$ aq. $\mathrm{MeOH}$ fraction from $C$. soldanella in HepG2 cells, the expression of G0/G1 phase cell cycle checkpoint proteins, including cyclin D1, cyclin E, CDK2, CDK4, and CDK6, was examined. As shown in Fig. 3A, the $85 \%$ aq. $\mathrm{MeOH}$ fraction of $C$. soldanella significantly decreased the protein levels of cyclin D1, cyclin E, CDK2, CDK4 and CDK6.

Treatment with 3,6 , or $12 \mu \mathrm{g} / \mathrm{ml}$ of the C. soldanella $85 \%$ aq. $\mathrm{MeOH}$ fraction significantly reduced cyclin D1 (81.9, 64.2 and $23.5 \%)$ and cyclin $\mathrm{E}(62.5,50.4$ and $24.0 \%)$ expression in a concentration-dependent manner. Also, treatment with 3,6 , or $12 \mu \mathrm{g} / \mathrm{ml}$ of the $85 \%$ aq. MeOH fraction reduced CDK4 expression in HepG2 cells compared with the control group by $114.1,109.7$ and $78.5 \%$, respectively. Moreover, treatment with 3,6 , or $12 \mu \mathrm{g} / \mathrm{ml}$ of the $85 \%$ aq. $\mathrm{MeOH}$ fraction reduced CDK6 expression in HepG 2 cells compared with the control group by $96.3,68.7$ and $46.5 \%$, respectively.

To investigate the cell cycle arrest of HepG2 cells induced by treatment with the $85 \%$ aq. $\mathrm{MeOH}$ fraction from C. soldanella, the expression of $\mathrm{S}$ phase cell cycle checkpoint proteins, including cyclin A, CDK2, and CDC25A, was examined. As shown in Fig. 3B, the $85 \%$ aq. $\mathrm{MeOH}$ fraction from C. soldanella significantly decreased the protein levels of cyclin A, CDK2, and CDC25A. In particular, treatment with 3,6 , or $12 \mu \mathrm{g} / \mathrm{ml}$ of the $C$. soldanella $85 \%$ aq. $\mathrm{MeOH}$ fraction resulted in significantly reduced CDK2 expression in a concentration-dependent manner with values of 78.5, 56.8 and $47.5 \%$, respectively.
$85 \%$ aq. MeOH C. soldanella

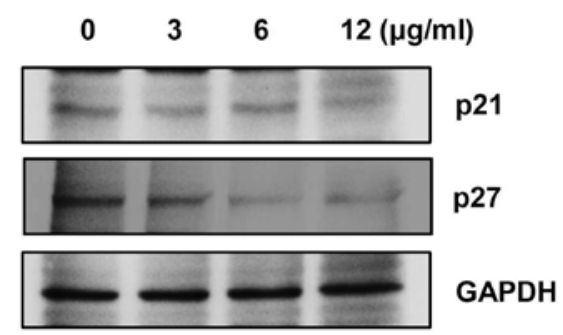

Figure 4. Effects of the $85 \%$ aq. $\mathrm{MeOH}$ fraction of $C$. soldanella on the level of CDK inhibitors in HepG2 cells. The cells were treated with the indicated concentrations of the $85 \%$ aq. $\mathrm{MeOH}$ fraction from $C$. soldanella for $24 \mathrm{~h}$. The cell lysates were separated, and equal amounts of total cell lysate were subjected to SDS-PAGE analysis. Protein levels of p21 and p27 were examined by western blotting. Data are presented as the mean $\pm \mathrm{SD}(\mathrm{p}<0.05)$ from three independent experiments.

Treatment with the C. soldanella $85 \%$ aq. MeOH fraction decreases the expression of $C D K$ inhibitors in HepG2 cells. Cyclin D/CDK4/6 and cyclin E/CDK2 complexes are important for the cell cycle transition from $\mathrm{G} 1$ into $\mathrm{S}$ phase, and these complexes are negatively regulated by CDK inhibitors, such as p21 and p27. As shown in Fig. 4, treatment with the $85 \%$ aq. $\mathrm{MeOH}$ fraction of $C$. soldanella significantly decreased the expression of p21 and p27.

Treatment with 3, 6, or $12 \mu \mathrm{g} / \mathrm{ml}$ of the $85 \%$ aq. MeOH fraction from $C$. soldanella significantly reduced $\mathrm{p} 21$ expression in a concentration-dependent manner, with values of 85.6, 86.1 and $70.4 \%$, respectively. Also, treatment with 3,6 , or $12 \mu \mathrm{g} / \mathrm{ml}$ of the $85 \%$ aq. $\mathrm{MeOH}$ fraction from $C$. soldanella reduced $\mathrm{p} 27$ expression in HepG2 cells compared with the control group by $89.4,74.3$ and $50.9 \%$, respectively.

Treatment with the $85 \%$ aq. MeOH fraction of $\mathrm{C}$. soldanella downregulates $R B$ phosphorylation and E2F expression in HepG 2 cells. As cyclin D and cyclin E-induced CDK activity converges in hyperphosphorylation of the RB protein, the 


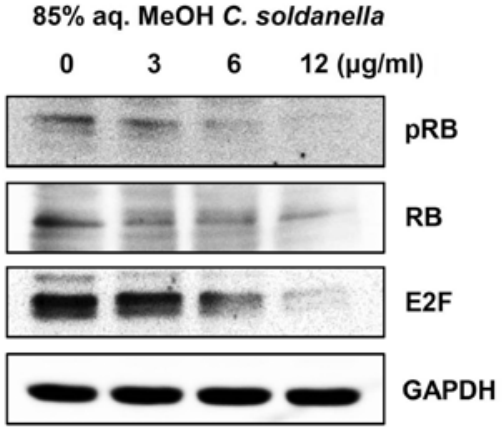

Figure 5. Effects of the $85 \%$ aq. $\mathrm{MeOH}$ fraction of C. soldanella on the level of pRB, RB, and E2F in HepG2 cells. The cells were treated with the indicated concentrations of the $85 \%$ aq. $\mathrm{MeOH}$ fraction from $C$. soldanella for $24 \mathrm{~h}$. The cell lysates were separated, and equal amounts of total cel lysate were subjected to SDS-PAGE analysis. Protein levels of pRB, RB, and E2F were examined by western blotting. Data are presented as the mean $\pm \mathrm{SD}(\mathrm{p}<0.05)$ from three independent experiments.

effect of treatment with the $85 \%$ aq. $\mathrm{MeOH}$ fraction from C. soldanella on the phosphorylation status of RB was examined using western blotting. As shown in Fig. 5, treatment with the $85 \%$ aq. $\mathrm{MeOH}$ fraction significantly decreased the expression of phosphorylated RB (pRB) and RB.

$\mathrm{E} 2 \mathrm{~F}$ is an important transcription factor for cell cycle progression from G1 to $\mathrm{S}$ phase and DNA synthesis. The effect of the $85 \%$ aq. $\mathrm{MeOH}$ fraction from C. soldanella on the level of E2F was examined. Treatment with the $C$. soldanella $85 \%$ aq. $\mathrm{MeOH}$ fraction significantly reduced the expression of E2F. In particular, treatment with 3,6 , or $12 \mu \mathrm{g} / \mathrm{ml}$ of the $85 \%$ aq. $\mathrm{MeOH}$ fraction resulted in significantly reduced $\mathrm{E} 2 \mathrm{~F}$ expression in a concentration-dependent manner, with values of $84.6,65.1$ and $42.1 \%$, respectively.

\section{Discussion}

We screened cytotoxicity of crude extract from $C$. soldanella against various human cancer cell including HepG2 hepatocellular, AGS gastric, HT-29 colon, and MCF-7 breast cancer cell in $50 \mu \mathrm{g} / \mathrm{ml}$ concentration. As a result, the cytotoxicity against HepG2 (37\%) and HT-29 (36\%) cancer cells was the greater compared to AGS (27\%) and MCF-7 (14\%) cancer cells (data not shown). This study reports the anticancer effect in HepG2 human cancer cells for the first time.

The purpose of this study was to investigate the viability of crude extracts and four solvent-partitioned fractions from C. soldanella in HepG2 human hepatocellular carcinoma cells. $C$. soldanella was extracted with methylene chloride and methanol, and the combined extract was partitioned into the $n$-hexane, $85 \%$ aq. $\mathrm{MeOH}, n-\mathrm{BuOH}$, and water fractions. The crude extract and four solvent fractions were examined using a cell viability assay, in which the $85 \%$ aq. $\mathrm{MeOH}$ fraction showed the greatest inhibition of proliferation in HepG 2 cells at a concentration of $50 \mu \mathrm{g} / \mathrm{ml}(97 \%$ compared with the control group; Fig. 1). The effect of the $85 \%$ aq. $\mathrm{MeOH}$ fraction from C. soldanella on cell viability was examined in HepG2 cells. Treatment with the $C$. soldanella $85 \%$ aq. $\mathrm{MeOH}$ fraction reduced viability concentration-dependently (Fig. 2).

Apoptosis (regulated cell death), occurs during normal homeostasis, disease, and development, and is characterized by morphological changes, including cell shrinkage, membrane blebbing, nuclear fragmentation, chromatin condensation, and an increase in the population of sub-G1 cells $(51,52)$. The $85 \%$ aq. $\mathrm{MeOH}$ fraction of $C$. soldanella induced apoptotic nuclear morphological changes in HepG2 cells. Thus, the $85 \%$ aq. $\mathrm{MeOH}$ fraction increased the rate of apoptosis compared with the control $(12 \mu \mathrm{g} / \mathrm{ml}, 44.27 \%$; and control, 20.85\%; data not shown).

Because treatment with the $85 \%$ aq. $\mathrm{MeOH}$ fraction resulted in the greatest inhibition of cell growth, we evaluated the cell cycle distribution and expression of cell cycle checkpoint proteins. As shown in Table I, treatment with the $C$. soldanella $85 \%$ aq. $\mathrm{MeOH}$ fraction induced $\mathrm{G} 0 / \mathrm{G} 1$ arrest $(12 \mu \mathrm{g} / \mathrm{ml}$, 69.60\%; and control, 60.47\%) and S phase arrest $(12 \mu \mathrm{g} / \mathrm{ml}$, 16.77\%; and control, 12.87\%) in HepG2 cells. Therefore, our results suggest that treatment with the $85 \%$ aq. $\mathrm{MeOH}$ fraction reduces cell growth of HepG2 cells through cell cycle arrest in G0/G1 and S phase and induces apoptosis.

Cancer cells exhibit deregulation of the cell cycle, increased apoptosis, and activation of signaling pathways that result in abnormal growth. Cyclins and CDKs are critical for appropriate regulation of the cell cycle, and altered formation of cyclin/CDK complexes has been shown to increase or decrease cell growth and affect proliferation and/or differentiation by apoptosis $(53,54)$. Cyclin D/CDK4/6 complexes and cyclin E/ CDK2 complexes are critical factors for progression through the G0/G1 phase of the cell cycle. These factors are negatively regulated by $\mathrm{CDK}$ inhibitors, such as p21 and p27 (55,56). To investigate the cell cycle arrest induced by treatment with the $85 \%$ aq. $\mathrm{MeOH}$ fraction from $C$. soldanella in HepG2 cells, expression of the $\mathrm{G} 0 / \mathrm{G} 1$ phase cell cycle proteins, including cyclin D1, cyclin E, CDK2, CDK4, CDK6, p21, and p27, was examined. As shown in Figs. 3A and 4, the $85 \%$ aq. $\mathrm{MeOH}$ fraction of $C$. soldanella significantly decreased the protein levels of cyclin D1, cyclin E, CDK2, CDK4, CDK6, p21, and p27.

Cyclin A, CDK2, and CDC25A are important factors for the $\mathrm{S}$ phase of the cell cycle. CDC25A is activated by cyclin A/ CDK2 complexes. These complexes allow for progression of the cell cycle, and increased expression of CDC25A promotes cell growth $(57,58)$. We have demonstrated that treatment with the $C$. soldanella $85 \%$ aq. $\mathrm{MeOH}$ fraction significantly decreased the protein levels of cyclin A, CDK2, and CDC25A (Fig. 3B).

The cell cycle proteins E2F and pRB are known to play important roles in cell cycle progression from $\mathrm{G} 1$ to $\mathrm{S}$ phase. Dephosphorylation of RB inhibits cell cycle progression by interacting with transcription factors of the E2F family, but phosphorylation of RB induces cell cycle progression by reducing $\mathrm{pRB} / \mathrm{E} 2 \mathrm{~F}$ complexes $(55,56)$. We showed that treatment with the $85 \%$ aq. $\mathrm{MeOH}$ fraction decreased expression of E2F and pRB, thus inhibiting the G1-S phase transition in HepG2 cells (Fig. 5). Overall, the $C$. soldanella $85 \%$ aq. $\mathrm{MeOH}$ fraction exhibited anticancer activity in HepG2 cells by blocking the G0/G1 and $\mathrm{S}$ phases of the cell cycle and by decreasing the expression of important cell cycle check point proteins.

Previous studies have investigated the potential cytotoxic effects of $\mathrm{MeOH}$ and chloroform extracts from $C$. soldanella against human cancer cells, including A549 lung cancer cells 
and Col2 colon cancer cells (38). This report reveals for the first time the anticancer effect in HepG2 human hepatocellular carcinoma cells. The $85 \%$ aq. $\mathrm{MeOH}$ fraction from C. soldanella should be considered for its therapeutic potential in hepatocellular cancer treatment. It will be necessary to identify the components of the $85 \%$ aq. $\mathrm{MeOH}$ fraction with high performance liquid chromatography (HPLC), nuclear magnetic resonance spectroscopy (NMR), and mass spectroscopy (MS). Determining the composition of the $C$. soldanella $85 \%$ aq. $\mathrm{MeOH}$ fraction is important.

\section{Acknowledgements}

This study was supported by the Basic Science Research Program through the National Research Foundation of Korea funded by the Ministry of Education (grant no. 2012R1A6A1028677).

\section{References}

1. Li YL, Zhang J, Min D, Hongyan Z, Lin N and Li QS: Anticancer effects of 1,3-Dihydroxy-2-Methylanthraquinone and the ethyl acetate fraction of Hedyotis Diffusa Willd against HepG2 carcinoma cells mediated via Apoptosis. PLoS One 11: e0151502, 2016.

2. Jin S, Park HJ, Oh YN, Kwon HJ, Kim JH, Choi YH and Kim BW: Anti-cancer activity of osmanthus matsumuranus extract by inducing G2/M arrest and apoptosis in human hepatocellular carcinoma Hep G2 cells. J Cancer Prev 20: 241-249, 2015.

3. Lee JI, Kwak MK, Park HY and Seo Y: Cytotoxicity of meroterpenoids from Sargassum siliquastrum against human cancer cells. Nat Prod Commun 8: 431-432, 2013.

4. Siegel RL, Miller KD and Jemal A: Cancer statistics, 2015. CA Cancer J Clin 65: 5-29, 2015.

5. Tang Z, Zhou X, Lin Z, Yang B, Ma Z, Ye S, Wu Z, Fan J, Liu Y, Liu K, et al: Surgical treatment of hepatocellular carcinoma and related basic research with special reference to recurrence and metastasis. Chin Med J (Engl) 112: 887-891, 1999.

6. Yu Z, Luo X, Wang C, Ye J, Liu S, Xie L, Wang F and Bao J: Baicalin promoted site- 2 protease and not site-1 protease in endoplasmic reticulum stress-induced apoptosis of human hepatocellular carcinoma cells. FEBS Open Bio 6: 1093-1101, 2016.

7. Chen NH and Zhong JJ: Ganoderic acid Me induces G1 arrest in wild-type p53 human tumor cells while G1/S transition arrest in p53-null cells. Process Biochem 44: 928-933, 2009.

8. Kong CS, Um YR, Lee JI, Kim YA, Yea SS and Seo Y: Constituents isolated from Glehnia littoralis suppress proliferations of human cancer cells and MMP expression in HT1080 cells. Food Chem 120: 385-394, 2010.

9. Stan SD, Kar S, Stoner GD and Singh SV: Bioactive food components and cancer risk reduction. J Cell Biochem 104: 339-356, 2008.

10. Um YR, Kong CS, Lee JI, Kim YA, Nam TJ and Seo Y: Evaluation of chemical constituents from Glehnia littoralis for antiproliferative activity against HT-29 human colon cancer cells. Process Biochem 45: 114-119, 2010.

11. Mary JS, Vinotha P and Pradeep AM: Screening for in vitro cytotoxic activity of seaweed, Sargassum sp. against Hep-2 and MCF-7 cancer cell lines. Asian Pac J Cancer Prev 13: 6073-6076, 2012.

12. Shamsabadi FT, Khoddami A, Fard SG, Abdullah R, Othman HH and Mohamed S: Comparison of tamoxifen with edible seaweed (Eucheuma cottonii L.) extract in suppressing breast tumor. Nutr Cancer 65: 255-262, 2013.

13. Rubiolo JA, López-Alonso H, Roel M, Vieytes MR, Thomas O, Ternon E, Vega FV and Botana LM: Mechanism of cytotoxic action of crambescidin-816 on human liver-derived tumour cells. Br J Pharmacol 171: 1655-1667, 2014.

14. Russo GL, Russo M, Castellano I, Napolitano A and Palumbo A: Ovothiol isolated from sea urchin oocytes induces autophagy in the Hep-G2 cell line. Mar Drugs 12: 4069-4085, 2014.

15. Kawee-Ai A and Kim SM: Application of microalgal fucoxanthin for the reduction of colon cancer risk: Inhibitory activity of fucoxanthin against beta-glucuronidase and DLD-1 cancer cells. Nat Prod Commun 9: 921-924, 2014.
16. Malve H: Exploring the ocean for new drug developments: Marine pharmacology. J Pharm Bioallied Sci 8: 83-91, 2016.

17. Gudiña EJ, Teixeira JA and Rodrigues LR: Biosurfactants produced by marine microorganisms with therapeutic applications. Mar Drugs 14: 38, 2016.

18. Talero E, García-Mauriño S, Ávila-Román J, Rodríguez-Luna A, Alcaide A and Motilva V: Bioactive compounds isolated from microalgae in chronic inflammation and cancer. Mar Drugs 13: 6152-6209, 2015.

19. Li R: Marinopyrroles: Unique drug discoveries based on marine natural products. Med Res Rev 36: 169-189, 2016.

20. Kong CS, Lee JI, Kim YA, Kim JA, Bak SS, Hong JW, Park HY, Yea SS and Seo Y: Evaluation on anti-adipogenic acitivity of flavonoids glucopyranosides from Salicornia herbacea. Process Biochem 47: 1073-1078, 2012.

21. Hesp PA: Ecological processes and plant adaptations on coastal dunes. J Arid Environ 21: 165-191, 1991.

22. Maun MA: Adaptations of plants to burial in coastal sand dunes. Can J Bot 76: 713-738, 1998.

23. Lawlor DW and Cornic G: Photosynthetic carbon assimilation and associated metabolism in relation to water deficits in higher plants. Plant Cell Environ 25: 275-294, 2002.

24. Lee JI, Kong CS, Jung ME, Hong JW, Lim SY and Seo Y: Antioxidant activity of the halophyte Limonium tetragonum and its major active components. Biotechnol Bioprocess Eng; BBE 16: 992-999, 2011.

25. Ksouri R, Megdiche W, Falleh H, Trabelsi N, Boulaaba M, Smaoui A and Abdelly C: Influence of biological, environmental and technical factors on phenolic content and antioxidant activities of Tunisian halophytes. C R Biol 331: 865-873, 2008.

26. Kim YA, Kong CS, Lee JI, Kim H, Park HY, Lee HS, Lee C and Seo Y: Evaluation of novel antioxidant triterpenoid saponins from the halophyte Salicornia herbacea. Bioorg Med Chem Lett 22: 4318-4322, 2012

27. Kim YA, Kong CS, Yea SS and Seo Y: Constituents of Corydalis heterocarpa and their anti-proliferative effects on human cancer cells. Food Chem Toxicol 48: 722-728, 2010.

28. Oueslati S, Ksouri R, Pichette A, Lavoie S, Girard-Lalancette K, Mshvildadze V, Abdelly C and Legault J: A new flavonol glycoside from the medicinal halophyte Suaeda fruticosa. Nat Prod Res 28: 960-966, 2014.

29. Kong NN, Fang ST, Wang JH, Wang ZH and Xia CH: Two new flavonoid glycosides from the halophyte Limonium franchetii. J Asian Nat Prod Res 16: 370-375, 2014.

30. Fang ST, Liu X, Kong NN, Liu SJ and Xia CH: Two new withanolides from the halophyte Datura stramonium L. Nat Prod Res 27: 1965-1970, 2013

31. Bae CY, Hwang JS, Bae JJ, Choi SC, Lim SH, Choi DG, Kim JG and Choo YS: Physiological responses of Calystegia soldanella under drought stress. J Ecol Environ 36: 255-265, 2013.

32. Bae KH: The Medicinal Plants of Korea. Korea, Kyo-Hak publishing, Seoul, 2000.

33. Lee YS, Kwak CG and Kim NW: Nutritional characteristics of Calystegia japonica. Korean J Food Preserv 19: 619-625, 2012.

34. Takagi S, Yamaki M, Masuda K and Kubota M: Studies on the purgative drugs. IV. On the constituents of Calystegia japonica Choisy (author's transl). Yakugaku Zasshi 97: 1369-1371, 1977 (In Japanese)

35. Kim Y, Min HY, Park HJ, Lee EJ, Park EJ, Hwang HJ, Jin C, Lee YS and Lee SK: Suppressive effects of nitric oxide production and inducible nitric oxide synthase (iNOS) gene expression by Calystegia soldanella methanol extract on lipopolysaccharide-activated RAW 264.7 cells. Eur J Cancer Prev 13: 419-424, 2004.

36. Huang $\mathrm{Z}$ and Feng C: Experimental study on anti-inflammatory and analgesic effects of water extracts of Calystegia soldanella. Chin Arch Tradit Chin Med 6: 7, 2010.

37. Lee JI, Kim IH, Choi YH, Kim EY and Nam TJ: PTP1B inhibitory effect of alkyl p-coumarates from Calystegia soldanella. Nat Prod Commun 9: 1585-1588, 2014.

38. Min HY, Kim Y, Lee EJ, Hwang HJ, Park EJ and Lee SK: Cytotoxic activities of indigenous plant extracts in cultured human cancer cells. Nat Prod Sci 8: 170-172, 2002.

39. Ono M, Takigawa A, Kanemaru Y, Kawakami G, Kabata K, Okawa M, Kinjo J, Yokomizo K, Yoshimitsu H and Nohara T: Calysolins V-IX, resin glycosides from Calystegia soldanella and their antiviral activity toward herpes. Chem Pharm Bull (Tokyo) 62: 97-105, 2014. 
40. Ono M, Kawakami G, Takigawa A, Kabata K, Okawa M, Kinjo J, Yokomizo K, Yoshimitsu H and Nohara T: Calysolins X-XIII, resin glycosides from Calystegia soldanella, and their antiviral activity toward herpes simplex virus. Chem Pharm Bull (Tokyo) 62: 839-844, 2014.

41. Ono M, Takigawa A, Muto H, Kabata K, Okawa M, Kinjo J, Yokomizo K, Yoshimitsu H and Nohara T: Antiviral activity of four new resin glycosides calysolins XIV-XVII from Calystegia soldanella against Herpes Simplex Virus. Chem Pharm Bull (Tokyo) 63: 641-648, 2015.

42. Nidiry ES, Ganeshan G and Lokesha AN: Antifungal activity and isomerization of octadecyl $p$-coumarates from Ipomoea carnea subsp. fistulosa. Nat Prod Commun 6: 1889-1892, 2011.

43. Gaspar EMM: New pentasaccharide macrolactone from the European Convolvulaceae Calystegia soldanella. Tetrahedron Lett 40: 6861-6864, 1999.

44. Gaspar EMM: Soldanelline B-The first acylated nonlinear tetrasaccharide macrolactone from the European Convolvulaceae Calystegia soldanella. Eur J Org Chem 2001: 369-373, 2001.

45. Takigawa A, Setoguchi H, Okawa M, Kinjo J, Miyashita H, Yokomizo K, Yoshimitsu H, Nohara T and Ono M: Identification and characterization of component organic and glycosidic acids of crude resin glycoside fraction from Calystegia soldanella. Chem Pharm Bull (Tokyo) 59: 1163-1168, 2011.

46. Takigawa A, Muto H, Kabata K, Okawa M, Kinjo J, Yoshimitsu H, Nohara T and Ono M: Calysolins I-IV, resin glycosides from Calystegia soldanella. J Nat Prod 74: 2414-2419, 2011.

47. Asano N, Yokoyama K, Sakurai M, Ikeda K, Kizu H, Kato A, Arisawa M, Höke D, Dräger B, Watson AA, et al: Dihydroxynortropane alkaloids from calystegine-producing plants. Phytochemistry 57: 721-726, 2001.

48. Tatsuzawa F, Mikanagi Y and Saito N: Flower anthocyanins of Calystegia in Japan. Biochem Syst Ecol 32: 1235-1238, 2004.

49. Tori M, Ohara Y, Nakashima K and Sono M: Caffeic and coumaric acid esters from Calystegia soldanella. Fitoterapia 71 353-359, 2000
50. Ahn NR, Ko JM and Cha HC: Comparison of flavonoid profiles between leaves and stems of Calystegia soldanella and Calystegia japonica. Am J Plant Sci 3: 1073-1076, 2012.

51. Ashkenazi A: Targeting the extrinsic apoptosis pathway in cancer. Cytokine Growth Factor Rev 19: 325-331, 2008.

52. Yang Y, Zhu X, Chen Y, Wang X and Chen R: p38 and JNK MAPK, but not ERK1/2 MAPK, play important role in colchicine-induced cortical neurons apoptosis. Eur J Pharmacol 576: 26-33, 2007.

53. Canavese M, Santo L and Raje N: Cyclin dependent kinases in cancer: Potential for therapeutic intervention. Cancer Biol Ther 13: 451-457, 2012.

54. Sperka T, Wang J and Rudolph KL: DNA damage checkpoints in stem cells, ageing and cancer. Nat Rev Mol Cell Biol 13: 579-590, 2012.

55. Dobashi Y, Takehana T and Ooi A: Perspectives on cancer therapy: Cell cycle blockers and perturbators. Curr Med Chem 10: 2549-2558, 2003.

56. Paternot S, Bockstaele L, Bisteau X, Kooken H, Coulonval K and Roger PP: Rb inactivation in cell cycle and cancer: The puzzle of highly regulated activating phosphorylation of CDK4 versus constitutively active CDK-activating kinase. Cell Cycle 9: 689-699, 2010

57. George Rosenker KM, Paquette WD, Johnston PA, Sharlow ER, Vogt A, Bakan A, Lazo JS and Wipf P: Synthesis and biological evaluation of 3-aminoisoquinolin-1(2H)-one based inhibitors of the dual-specificity phosphatase Cdc25B. Bioorg Med Chem 23: 2810-2818, 2015

58. Tilaoui M, Mouse HA, Jaafari A and Zyad A: Differential effect of artemisinin against cancer cell lines. Nat Prod Bioprospect 4: 189-196, 2014. 